
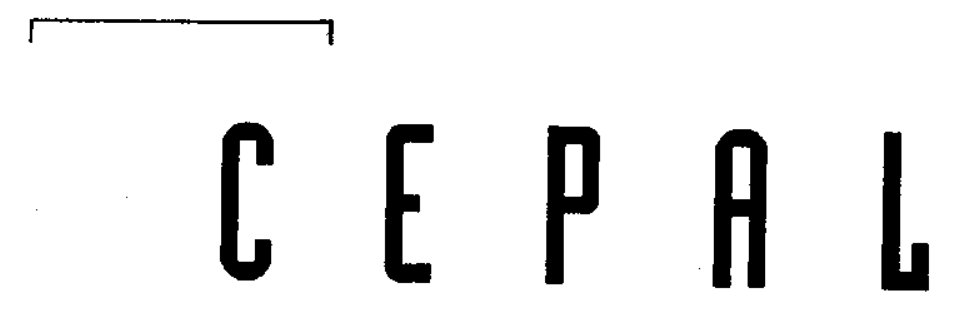

REVIE W

\author{
NUM BER 64 \\ A P P L 1998 \\ SANTIAGO, CHILE \\ O S C A R ALTIMIR \\ Director of the Review \\ EUGENIO LAHERA \\ Technical Secretary
}

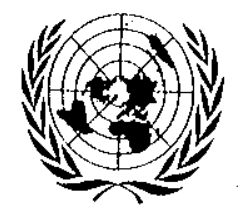

UNITED NATIONS 


\section{O NTENTS}

Instltutions and growth: can human capital be a link?

Nauro Campos and Jeffrey B. Nugent

External capital flows in Latin America and the Carlbbean

In the 1990s: experiences and policies

Gunther Held and Raquel Szalachman

The Central Bank and Chilean macroeconomic policy in the 1990s

Roberto Zahler

Fiscal policy, cycles and growth

Ricardo Martner

Best practices, pollcy convergence and the WTO

trado-related investment measures

Francisco Sercovich

Posslble effects of European Union widening

on Latin America

Peter Nunnenkamp

The North-South dimension of the environmental and cleaner technology Industrles

Jonathan $R$. Barton

The evolution of the State's role in the regulation of land transport

Ian Thomson

Integrated water management from the perspective

of the Dublin Principles

Miguel Solanes 


\section{The North-South dimension of the environmental and cleaner technology industries}

\section{Jonathan R. Barton}

School of Development Studies, University of East Anglia, Norwich, United Kingdom.
The environment industry, which includes a wide range of products and services relating to the monitoring, treatment, control and management of industrial and domestic pollution, has grown rapidly during the $1980 \mathrm{~s}$ and $1990 \mathrm{~s}$ as a response to environmental regulations. Due to the relatively early application of these regulations in the United States, Europe and Japan, these areas have become competitive producers and exporters of environmental products and services. As the industrial sector has developed, environmental awareness has been raised and competition and international trade in the environment industry have expanded. There is now a clear North/South dimension in international patterns of development of the industry and its trade. Whilst environment industries were established to deal with waste reduction and disposal strategies, there has also been a drive towards cleaner production. The European environmental and cleaner technology industries are reviewed in order to establish their competitiveness and the shift between the two different approaches to environmental management: amelioration by environmental industries and prevention by cleaner process and production technologies. In this respect, Latin American provides a contrasting example. The nature of the expansion of the industrial environmental management sector in the region is questioned, particularly with regard to the composition of the sector and the way it is interpreted in different countries. The paper suggests that the environment industry and cleaner technologies should be understood as industries rather than as unquestionably "environmentally positive" sets of products and services. The extent to which these industries reveal an information and technology gap in environmental management is also analysed. This gap may, on the one hand, assist environmental managers in the South, but on the other it may lead to a condition of environmental management dependence. 
I

\section{The relationship between the}

\section{environment and industry}

This relationship has been central to many of the debates on Latin American development since 1972, when the Stockholm Declaration raised consciousness of the impacts of environmental contamination. In the twenty-five years since that Declaration, Latin America's urban environments have provided prominent case studies in such areas as environmental degradation and innovative environmental policies. Environmental stress has been pivotal in debates relating to urban planning, health and economic development. For these reasons, the nature of the changes in the environment/industry linkage are especially deserving of attention now, in the mid1990 s, since after twenty years of relatively unchecked industrial pollution, the last five years have brought considerable developments in the environment/industry relationship. The principal changes relate to the emergence of "environment industries" and the extent to which these industries can bring about the promotion of cleaner production in Latin America's "dirtier" industries.

The emergence of environment industries, especially those firms engaged in the production of goods and services aimed at the reduction of contamination (principally "end-of-pipeline" technologies), was observed throughout the world during the 1980 s as a response to tighter regulatory systems. While the United States, Japan and Germany have been the "first movers" in terms of environment industry development, the role of the environment industry in Latin American industrial development in the next century will be a significant one, both in terms of the provision of goods and services and also improvements in Latin American environmental quality.

This paper will address the changes that have taken place in the environment/industry relationship over time and stress the important role that environment industries will play in the early part of the next century and the need for Latin American firms and governments to be aware of these developments and to respond to them. If the environment industries' goods and services continue to be supplied mainly by foreign firms, the future costs for Latin American firms will have significant impacts on export product prices and will threaten the economic successes of the export-led models.

Whilst the debates relating to environmental regulation and its effects on industrial competitiveness continue to divide industrialists and environmentalists, the impacts of those regulations -as well as of failure to regulate- are being experienced on a global basis. ${ }^{1}$ The links between economy and environment, as well as the social consequences of those links, are fully recognized by multilateral institutions (Munasinghe and Cruz, 1995). A significant outcome of the environmental regulation of industrial sectors has been the emergence of a vast sector that has become known as the environment industry. This industry has expanded to accommodate the demands of increasing numbers of industries that must take heed of environmental policy recommendations; the European Union has already issued 160 Directives in this respect, for example (European Commission, 1994a). In order to meet the new regulations, industries have had to invest significantly in pollution abatement and control (see table 1).

In many ways the development of the environment industry and cleaner technologies, and the debates on them, are an extension of previous debates relating to industrial relocation to "pollution havens", and "industrial flight" more generally (see Stafford, 1985; Hesselberg and Knutsen, 1994). These debates were concerned with the movement of "dirty" industries out of regions with strict environmental regulations to regions with slacker regulations. There was a clear North/South dimension to these debates, and there continues to be a strong similar dimension to the environment industry and the diffusion of cleaner

\footnotetext{
${ }^{1}$ This paper forms part of the European Commission's Fourth Framework Project on Environment and Climate, entitled "Envjronmental regulations, globalization of production and technological change." The author wishes to express his thanks to Rhys Jenkins for his comments.
} 
TABLE 1

Pollution abatement and control expenditure

(As a percentage of gross fixed capital formation)

\begin{tabular}{|c|c|c|c|c|c|c|c|}
\hline & \multicolumn{2}{|c|}{ Public sector } & \multicolumn{2}{|c|}{ Business sector } & \multicolumn{2}{|c|}{ Total } & \multirow{2}{*}{$\frac{\% \text { of GDP }}{1990}$} \\
\hline & 1985 & 1990 & 1985 & 1990 & 1985 & 1990 & \\
\hline United States & 1.1 & 1.4 & 2.0 & 2.0 & 3.1 & 3.4 & - \\
\hline Japan & 2.9 & 2.6 & 0.5 & 0.3 & 3.4 & 3.0 & - \\
\hline Germany & 1.9 & 2.1 & 1.6 & 1.4 & 3.5 & 3.5 & 1.6 \\
\hline France & 0.8 & 0.7 & 0.4 & 0.4 & 1.2 & 1.1 & 1.0 \\
\hline Italy & 1.0 & 0.9 & - & - & - & - & 0.8 \\
\hline Austria & 2.7 & - & - & 1.0 & - & - & - \\
\hline Denmark & 1.0 & 1.8 & - & - & - & - & 1.1 \\
\hline Netherlands & 2.2 & 1.0 & 1.0 & 1.3 & 3.2 & 2.3 & 1.4 \\
\hline Portugal & 1.0 & 1.0 & 0.5 & 0.7 & 1.5 & 1.6 & 0.8 \\
\hline Spain & 0.6 & 0.8 & - & $\therefore$ & - & - & 0.6 \\
\hline Sweden & - & - & 0.8 & 1.2 & - & - & - \\
\hline
\end{tabular}

Source: OECD (1993a) and European Commission (1994a).

technologies, even though research has revealed that generally speaking "dirty" firms have not been forced to relocate in response to regulatory pressures (Leonard, 1984 and 1988).

Whilst environmental regulations in North America, Western Europe and Japan sought to reduce contamination and, it was thought, might lead to the expulsion of "dirty" industries, the environment industry firms which developed to respond to the demands of the regulated industries became "first movers" and are now well placed to benefit from the globalization of environment regulation policies. For this reason, the emergence of strong European environmental industries and cleaner technology initiatives during the 1980 s and 1990s has led to potential advantages in terms of trade in European environmentally-based goods and services. It was in Germany and the Netherlands that the environment industries were promoted most keenly during the 1980s, following the swift adoption of new standards, a sharp increase in public spending on R\&D, and aggressive strategies of firms in the environment market (European Commission, 1989). These countries continue to be market leaders in environmentrelated goods and services.

The notion of "first movers" is seen to be integral to the environment and cleaner technology industries. Much of the R\&D in the sector is based on the realization that good returns on capital investment will be forthcoming in the longer term as regulations become more widespread and stricter, thus requiring improved technologies and management strategies. To be a "first mover" is to benefit from competitive advantages in the marketplace and is considered to be a fundamental factor behind the development process. Since the high costs of R\&D have been prohibitive in many areas of the world where regulatory frameworks remain lax or not intensively implemented, the "first mover" advantages have accrued to firms based in countries which had strict regulations from an early stage, such as the United States, Germany and Japan. These firms, having risked capital in $R \& D$ in the stages of innovation, are now able to profit from growing demand as similar regulations elsewhere in the world have prompted a need for their goods and services. The link between regulatory models and environment industry trade is very strong: thus, for example, the United States regulatory system was adopted in Mexico, and United States firms have supplied that market.

With regard to cleaner technologies, the costs of R\&D are often prohibitive since, in many cases, an overhaul of the entire production system is required in order to assess the areas of greatest possible benefits. Nevertheless, the advantages of being a "first mover" remain the same, and it is likely that cleaner systems will be increasingly in demand in the near future as public environmental pressure works through the political apparatus into regulatory policies. There is little likelihood of continued high demand for "end-of-pipeline" technologies, due to increasing waste disposal costs and the problem of competition from firms that have low waste output; internal factors such as product quality, raw material costs and energy requirements also need to be considered in this respect (Rajagopal, 1992). Investment 
in the environment industry is a recognition of the need to keep pace with the rapid changes taking place in environmental regulation and management; in Germany, for example, the environment industry invests an average of $3.1 \%$ of its turnover in $R \& D$, compared with only $1.8 \%$ in manufacturing generally (Vickery and Iarrera, 1996). It is likely that Germany will maintain its predominant position in Europe within this sector.

The environment industry is a supplier of technology and associated services such as consultancy, maintenance and upgrading. The industry is both highly sophisticated yet "low-tech" in terms of the products supplied in response to the broad range of industrial and environmental requirements: low-tech components such as simple lagging of existing equipment in order to reduce heat waste or water loss are as important as hi-tech equipment such as flue gas desulphurization plants. "Low" technology is an important theme within the environment industry, especially in the context of the South. For example, a report by the United States International Trade Commission (1995, pp. 6-22) on the United States municipal and industrial water and wastewater technology industry revealed that United States products were often seen as too sophisticated and expensive, and that less sophisticated approaches might be appropriate in many cases for export to less developed economies.

Cleaner technology is different from the activities of the environment industries in that it seeks to reorganize the production process in order to reduce waste, in contrast with the environment industries' focus on dealing with waste that remains from industrial processes. Although many definitions class these two areas of industrial environmental management together, for the purposes of this paper they will be dealt with as separate approaches, because of their fundamentally different positions regarding how waste and contamination should be controlled.

In terms of growth, the environment industry (in this case including cleaner technologies) is one of the fastest-growing sectors in the global economy. In 1992, Bill Clinton noted that the environmental goods and services industry was "The only sector of our economy that has shown an unexpected level of growth in the past five years" (Corriere della Sera, 10 November 1992, quoted by Malaman, 1996). Similar growth rates have also been experienced in Europe and Japan. Clinton followed up this statement in 1993 by directing United States government agen- cies to assess environmental technologies and their competitiveness and to develop trade, financing and technical strategies to increase environment industry exports and jobs (United States Department of Commerce, 1994a and b). This strong State support for a surging industrial sector reveals the perceived current and future importance of the environment industry within the global economy.

The environment industry is centered around the production of pollution control equipment and waste treatment and disposal. These two areas give rise to the nine principal subdivisions of the industry's activities: waste management; wastewater treatment; air pollution control; energy management; marine pollution control; environmental monitoring and instrumentation; environmental services; noise and vibration control; and contaminated land rehabilitation. Together, the concerns operating in these areas have built up a US\$ 200 billion industry (1990) that is expected to grow 50\% by the year 2000 (OECD, 1992a). The World Bank's International Finance Corporation doubles the estimate for the year 2000, thus putting the environmental industry's annual market higher than that of the chemical industry (IFC, 1992; Karliner, 1994).

The delineation of the subsectors of the environment industry listed above is a thorny problem which has preoccupied those involved in research relating to this sector. The 1992 OECD report on the industry (OECD, 1992a), which was the first to review the industry as a whole, was hampered by the difficulties of how the industrial sector was interpreted and measured by different member States of the OECD (see box 1). This ongoing problem of definition continues to make data analysis problematical. The Washington Meeting on the environment industry in October 1994 also struggled with these difficulties. Whilst authors are still trying to clarify how they and particular States interpret the terms "environment industry", "environmental industry", "eco-business" or "eco-industry", the difficulties of comparative analysis will remain highly complex (see Noble, 1996; Gaston and Santiago, 1996). For example, the definition put forward by the European Commission (1994) is broad, but so extensive as to be difficult to work with: "Eco-industries ... may be described as including firms producing goods and services capable of measuring, preventing, limiting or correcting environmental damage such as the pollution of water, air, soil, as well as waste- and noise-related problems. They include clean technologies where pollution and raw material use is being minimized." 
Box 1

DEFINITIONS OF THE ENVIRONMENT INDUSTRY IN SELECTED COUNTRIES

United States Government - "Environmental Technology"

"A technology that advances sustainable development by reducing risk, enhancing cost effectiveness, improving process efficiency, and creating products and processes that are environmentally beneficial or benign. The word "technology" is intended to include hardware, software, systems and services."

Japan, Ministry of International Trade and Industry -"Eco-business" "Industrial sectors with a potential to help reduce environmental burdens"

Australian Industry Commission - "Environmental waste management equipment, systems and services industry" "A diverse collection of industrial producers and service providers encompassing any entity providing technology or service-related solutions to solid, liquid, or gaseous waste management problems. Thus it embraces parts of product-based industry sectors engaged in engineering, construction, design, scientific instrumentation and consultancy services."

Netherlands (Association of Suppliers of Environmental Equipment)

"Companies producing, supplying and/or installing (parts of) equipment/machines for the abatement of environmental damage (excluding noise hindrance) as well as companies advising on environmental issues"

Source: OECD (1993a).

The difficulties of definition become particularly complex when the issue of clean technologies is considered, since it is difficult to separate these technology improvements from other improvements (OECD, 1995). The OECD's 1992 definition did not include the clean technology dimension, however the division between environment industry and clean technology is not a transparent one. The definition varies widely acconding to sources, due to the relatively recent association of environmentally-related products and services with large-scale industry and international trade.

The wide-ranging nature of the products and services involved, from consultancy and monitoring to "end-of-pipeline" technologies and cleaner production technologies, complicates the international trade picture even further. More recently, the OECD (1996a) has delineated the industry into three areas: environmental equipment, environmental services and integrated environmental technologies (cleaner industrial processes and products) (see box 2 and table 2). In this way, the OECD makes the separation of cleaner technologies explicit. At the national level, the United States, Canada and Japan have broad definitions of the environment industry whilst Italy, Norway and Germany, for example, have chosen narrower ones (see Vickery and Iarrera, 1996); in Japan, the definition is so wide-ranging that all municipal services are included. The reasons for such divergent definitions are connected with the rapid innovations in environment industries and the wide range of services, equipment and applications that are used by industry. Since the industrial make-up of national economies varies con-

\section{Box 2}

BREAKDOWN OF THE ENVIRONMENT INDUSTRY

Environmental equipment

Waste-water treatment equipment

Waste management and recycling equipment

Air pollution control equipment

Noise reduction equipment

Monitoring instruments and scientific, research and laboratory equipment

Natural resource conservation/protection and urban amenities

\section{Environmental services}

Waste-water operations

Waste handling facility operations

Noise reduction operations

Analytical, monitoring and related conservation and protection services

Technical and engineering services

Environmental research and development

Environmental training and education

Accounting and legal services

Consulting services

Other environmental business services

Others: eco-tourism

Cleaner technologies: Integrated environmental technologies

Cleaner production equipment

Efficient energy generation and conservation equipment Eco-products

Source: OECD (1996a). 
Main components of the environment industry, 1990

(Percentages)

\begin{tabular}{lccccccc}
\hline & N.America & Europe & Japan & Total, OECD & \multicolumn{2}{c}{ Billions of ECU } & $\begin{array}{c}\text { Estimated } \\
\text { growth per } \\
\text { annum (\%) }\end{array}$ \\
\hline Equipment/related services & 74 & 76 & 79 & 76 & 119 & 172 & 5.0 \\
Water and effluent treatment & 24 & 34 & 22 & 29 & 47 & 65 & 4.0 \\
Waste management & 25 & 15 & 22 & 21 & 31 & 49 & 6.4 \\
Air quality control & 12 & 17 & 25 & 15 & 23 & 33 & $\mathbf{4 . 4}$ \\
Other (land rehabilitation, noise) & 13 & 10 & 10 & 11 & 17 & 25 & $\mathbf{5 . 1}$ \\
General services & 26 & 24 & 21 & 24 & 37 & 62 & 7.4 \\
Total & 100 & $\mathbf{1 0 0}$ & $\mathbf{1 0 0}$ & $\mathbf{1 0 0}$ & $\mathbf{1 5 6}$ & $\mathbf{2 3 4}$ & $\mathbf{5 . 5}$ \\
\hline
\end{tabular}

Source: European Commission, 1994a, based on OECD data.

siderably, the range of goods and services included within the definition of "environment industry" has also been variable.

There is clearly a need for a universal definition that can be applied for comparative purposes, but the difficulty of classifying what goods and services are explicitly environmentally related, rather than industrial per se, will be a considerable problem. There is a great danger that almost all innovations that lead to reductions in waste and contamination will be labelled environmental, even when these reductions are incidental rather than of a priority nature. At the Washington Meeting on the environment industry in 1994, it was acknowledged that consistent data collection had hampered the analysis of the industry and that one way forward would be the identification of core and non-core groups of products (Vickery and Iarrera, 1996). The core group would include producers of "end-of-pipeline" and clean-up equipment and suppliers of associated environmental services, as well as services with a clear single environmental purpose. The non-core group would include cleaner products and cleaner technologies, as well as intermediate products (so-called multi-use products).

A working definition used in this paper is that the environment industry is a supplier of technology and its associated services such as consultancy, maintenance and upgrading. It is at once highly sophisticated and "low-tech" and is one of the fastest expanding sectors in the global economy. Its raison d'être is the reduction and disposal of waste from the final stages of industrial production. Cleaner technologies are associated with the environment industry but can be differentiated from it in terms of approach, in that cleaner technologies seek to reduce waste by reviewing and altering the entire industrial process, thus reducing the need for "end-of-pipeline" strategies. The United States provides the largest environment industry market at $39 \%$ of the global market, while the European Union accounts for $24 \%$ of the global market, with Germany predominating with $36 \%$ of the EU share. In terms of potential growth, Canada in particular has been increasing its environment industry's share of international markets (Fouillard, 1992; Higgins, 1996).

\section{II}

\section{The response to pollution regulation}

Regulation of "dirty" industries during the 1970 s led to the adoption of "end-of-pipeline" technologies and treatments for the most part. These technologies sought to reduce the emission of contaminants rather than change the production process and reduce the production of pollutants. The demand for "end-ofpipeline" technologies to curb emissions and respond to legislative regulations on pollution control resulted in the emergence of supplier firms. These firms were initially involved in other mechanical and engineering activities but responded to this new demand through diversification, or in many cases through the establishment of new small firms and consultancy offices. Later, some of the largest multinational firms 
TABLE 3

Global environment market

(Billions of U.S. dollars) ${ }^{\text {a }}$

\begin{tabular}{|c|c|c|c|c|c|c|c|c|}
\hline & \multicolumn{2}{|c|}{ OECD } & \multicolumn{2}{|c|}{ ECOTEC } & \multicolumn{2}{|c|}{ ETDC } & \multicolumn{2}{|c|}{$\begin{array}{c}\text { Environment } \\
\text { Business International }\end{array}$} \\
\hline & 1990 & 2000 & 1990 & 2000 & 1990 & 2000 & 1990 & 2000 \\
\hline \multicolumn{9}{|l|}{ North America } \\
\hline United States & 78 & 113 & 85 & 125 & 115 & 185 & 134 & 180 \\
\hline Canada & 7 & 12 & 14 & 18 & 7 & 14 & 10 & 17 \\
\hline Mexico & - & - & 1 & 5 & 3 & 18 & 1 & 2 \\
\hline Subtotal & 85 & 125 & 100 & 147 & 125 & 217 & 145 & 199 \\
\hline Latin America & - & - & $?$ & 5 & & & & \\
\hline \multicolumn{9}{|l|}{ Europe } \\
\hline France & 10 & 15 & 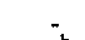 & - & 10 & 30 & - & - \\
\hline Germany & 17 & 23 & $60^{b}$ & $89^{\mathrm{b}}$ & 21 & 65 & 94 & 132 \\
\hline United Kingdom & 7 & 11 & - & - & 11 & 28 & - & - \\
\hline Rest of European Union & 12 & 20 & - & - & 15 & 48 & - & - \\
\hline Rest of Western Europe & 5 & 9 & - & - & 6 & 17 & - & - \\
\hline & 15 & 21 & 5 & 9 & 15 & & & \\
\hline $\begin{array}{l}\text { Independent States } \\
\text { Subtotal }\end{array}$ & 66 & 99 & 65 & 98 & 78 & $\begin{array}{r}25 \\
213\end{array}$ & 14 & 27 \\
\hline \multicolumn{9}{|l|}{ Asia-Pacific } \\
\hline Japan & 24 & 39 & 30 & 44 & 24 & 65 & 21 & 31 \\
\hline Australia/New Zealand & 2 & 3 & - & - & 2 & 4 & 3 & 5 \\
\hline Tajwan & - & - & - & - & 5 & 30 & - & - \\
\hline Hong Kong & - & - & $5^{\mathrm{c}}$ & $12^{\mathrm{c}}$ & - & 3 & - & - \\
\hline South Korea & - & - & - & - & 1 & 8 & - & - \\
\hline Rest of Asia-Pacific & - & - & - & - & 14 & 28 & 6 & 13 \\
\hline China & - & - & 2 & 5 & - & - & - & \\
\hline India & - & - & 1 & 2 & - & - & - & . \\
\hline Subtotal & 26 & 42 & 85 & 63 & 46 & 138 & 30 & 49 \\
\hline Rest of World & 21 & 34 & - & - & 6 & 12 & 6 & 9 \\
\hline Total World & 200 & 300 & 210 & 320 & 255 & 580 & 295 & 426 \\
\hline
\end{tabular}

Source: OECD, $1996 a$.

"The categorisation of environment products and services differs between the particular sources, especially in terms of the inclusion, exclusion and definition of "clean" technologies.

${ }^{b}$ All Western Europe.

c East and South East Asia.

saw the competitive advantages of supplying pollution control equipment. Joseph Karliner (1994), for example, points to the Dow Corporation and DuPont as two significant suppliers of pollution control equipment in the United States. He also mentions the specialist firm of Waste Management Technologies (WMX), which accounts for approximately $10 \%$ of the U.S. environment industry's earnings and rivals the aircraft manufacturer Lockheed in size. These large firms have been able to expand into international markets far more easily than the smaller firms, thanks to their existing organizational structures. For example, WMX has rapidly increased its operations in Europe since 1991, especially in the United Kingdom and France. In Europe, the German firm Deutsche Babcock was an early market leader, with a turnover of ECU 650 million as early as 1988 , but when this is compared with WMX's turnover of ECU 3 billion, the difference between the United States and European industries becomes more apparent (European Commission, 1989 and 1994a).

In terms of geography, the "first mover" advantage has led to the emergence of specialized environmental industry firms in those countries with early environmental regulation. Since environmental movements developed most strongly in the United States and Europe, it was there that the early regulation gave rise to environment industry development (see table 3). Japanese firms also emerged at the same time in response to air pollution problems. In Europe, the water and effluent treatment technology market is the best established within the EU environmental in- 
dustry, providing $34 \%$ of its output in value terms (European Commission, 1994a).

The outcome of the growth of specific core areas and specialization has been that certain countries have strong firms in particular core areas of the industry. In Japan, Mitsubishi and Hitachi lead in air pollution control equipment, whilst European firms have a "first mover" advantage in waste water treatment (the Dutch in contaminated land rehabilitation), and North American firms in waste treatment. The emergence of these firms, which now have strong comparative advantages in terms of $R \& D$ and production experience within the global marketplace for environmental goods and services, has been a direct response to early environmental regulation in specific countries. Consequently, it may be observed that there are two processes under way within the global environment industry: one is the specialization of firms based in particular countries in areas of the environment industry; the other is the geographical nature of the commercial relations that have developed in the trade and transfer of environmental goods and services. With regard to the first-named process, certain countries have sought to occupy niches in the global marketplace for environment goods and services, often with strong State support. As for the second process, particular countries have sought to dominate the trading relations of particular regions in the environmental industry. The most obvious exam- ples of this latter process are the promotion of United States environment goods and services in Latin America, and the similar prevalence of Japanese products and services in South East Asia (see Ecotec Research and Consulting Ltd., 1994). In the case of Japan, the government's environmental strategy entitled the "Environmental Vision of Industry" focused on improving environmental performance in fifteen targeted industrial sectors. The outcome has been that the expertise developed under this strategy can now be traded abroad.

As environmental regulations lead to a transition from "end-of-pipeline" technologies to fundamental changes in production processes, the firms in the North (essentially in North America, Western Europe and Japan) have sought to benefit from the increasing demand for environment goods and services in the South as environmental regulations begin to be enforced in response to (mainly international) environmental pressures. Karliner (1994, p. 60) notes that this is the third stage in a longer process of exporting toxic industrial development to the South: "firstly, economic 'development' is exported through free trade policies and financing by multilateral and bilateral agencies; secondly, environmental regulations to control the excesses of this development are introduced; finally, "environmental' technology and services are exported to service these regulations."

\section{III}

\section{Competition and trade in the}

\section{environment industry}

The environment industry is not homogeneous and is difficult to compare with many industrial sectors. Unlike the iron and steel industry, where the products are varied but share the same materials, the environment industry is much more difficult to unravel, particularly in the separation of products and services. For this reason, the development of the sector has not been uniform and technological, geographical and investment factors have followed different trajectories in the different core areas of the industry. It is the largest core areas -waste water treatment, waste management and air pollution control- that have aroused the greatest interest in terms of technological change and investment. Other sectors, due to their relative scale and development, have followed other development paths. For instance, environmental consultancy has grown considerably but, due to its human capital basis, does not attract large investment and is not so responsive to technological change as equipment production. Another example is the area of noise and vibration control, which, although prevalent in many contexts, is still in its infancy.

In line with scale of enterprise, demand and technology, there are clear sectoral divisions within the environment industry which reveal it to be a highly heterogeneous sector in many ways, such as 
capitalization, employment, rates of change, and human and technological intensity. For these reasons, patterns of competition and trade have been more difficult to track for the industry as a whole. The rapidity of growth during the 1980s and 1990s has been remarkable and has been matched by a parallel increase in competition and trade within the sector, in all the core areas. As with all examinations of the industry, however, it becomes fragmented once the issues of competition and trade are raised.

Like competition within the domestic (national) context, international competition has been dependent on the nature and longevity of regulations, as well as the ability of firms to set up operations and compete on equal terms. The issue of trade, for its part, raises the questions of international competition, the globalization of the environment industry, and the pursuit and development of new markets. It is in the context of the latter that the environment industry rates as a most important industrial sector, rivalling many other key industrial sectors such as pharmaceuticals and vehicles in terms of its North/South dimensions. With investment in research and development concentrated within firms based in the North, the trading patterns that have become most apparent in the industry, apart from particular horizontal links within and between North America, Europe and Japan, are those linking North and South (see table 4). These North/South links are critical to the development of the industry and have received considerable governmental export promotion support in many cases, most notably from the United States government.

Competition within the industry varies greatly from one country to another. Specific domestic regulations and their time scales of application have given some nations "first mover" advantages which have greatly favoured the firms catering for this sector and put them in a good position for expanding into international markets. Within this state of affairs, some firms have captured considerable shares of the market for certain products and services and have grown to a sufficient scale to compete internationally. An important issue within the competitiveness debate is the prevalent size of firms in the environment industry. Until the 1990s, the industry was characterised by small and medium-sized firms, but this has been changing considerably. In the mature environment industries of the United States and Germany, for instance, these firms are generally larger than the overall national average. In the United States the reason for this is the slowing growth rates of the industry in the 1990 s and an
TABLE 4

OECD trade in environment products, 1990

\begin{tabular}{lcc}
\hline & $\begin{array}{c}\text { Export share } \\
\text { (as a percentage of } \\
\text { production exported) }\end{array}$ & $\begin{array}{c}\text { Trade balance } \\
\text { (millions of } \\
\text { ECU) }\end{array}$ \\
\hline USA & 10 & 3120 \\
Europe & 20 & 6240 \\
Germany & 40 & 7800 \\
United Kingdom & 17 & 390 \\
France & 14 & 390 \\
Japan & 6 & 2340 \\
\hline
\end{tabular}

Source: European Commission, 1994a, based on OECD data.

increase in mergers and acquisitions (Vickery and Iarrera, 1996). In Germany, environment industry firms are larger than the national sectoral average as a result of the strong performance of the national environment industry and its high profile as a strategic sector (Walter and Horbach, 1996).

It is difficult to get a clear picture of competition across the board within the environment industry for two reasons: first, the rapidity of change within most core areas, and second, the wide range of sectors and subsectors, their definitions, and the size of operations, which make comparative analysis problematical. What is clear is that the competitive advantages of firms operating in one or more of the delineated fields within the industry depend heavily on R\&D. A setback for many firms is their operating size and the financial constraints, such as access to capital, that they face.

In international environment industry trade, Germany is the world's leading exporting country in terms of the proportion of its production exported. Thus, Germany exports $40 \%$ of its production in value terms, principally water treatment equipment and air pollution abatement technologies. The direction of German exports is divided between the European countries and more distant destinations such as North America, Eastern Europe, the Middle East and Africa. Within the European Union, the United Kingdom, Netherlands and France are also net exporters in terms of the environment industry, according to data for 1994 (OECD, 1996a). In the same way that strict national regulations initiated the development of Germany's environment industry, new pressures for cleaner technologies and process methods (both aimed at reducing the need for "end-of-pipeline"- style technologies) may well signify "first mover" or "market driver" advantages for that country into the first two decades of the next century. 


\section{IV}

\section{The European environment industry}

The European environment industry has become an important part of the national economies, particularly in Northern Europe, in terms of both domestic and international production and supply. It is a large sector in terms of employment and trade within the European Union, and is likely to continue to register a healthy growth rate for as long as the pressure for reduced environmental contamination continues, especially in view of its geographical proximity for trading with countries requiring environment products and services in Eastern and Central Europe.

Within Europe, Germany dominates the environment industry in terms of number and size of firms, production, employment and expenditure on environment industry products (see tables 6 and 7). As Germany established environmental regulation frameworks earlier than other European Union member States, its firms operating in this sector were able to enjoy "first mover" advantages when other States began establishing their own regulations. The rise and consolidation of the German environment industry and its success in export markets have made it Europe's leader in this sector, to such an extent that it is often monitored by the United States and Japan on its own rather than as part of the European Union. Within Europe, it is Germany which is the competitor rather than the Union as a whole.

The OECD (1996a) calculates that the German environment industry market (US $\$ 17.5$ billion in 1992) accounts for $30 \%$ of the European total. The reunification process, whereby a country with high environmental standards was merged with a country with low standards in this respect, has established a large domestic market for environmental products and services, although the extent to which the industry is able to take advantage of the demand on its doorstep will depend on the resources available for financing it. Financing the demand for environmental products and services is the greatest barrier to the development of the global environment industry, whether in Eastern and Central Europe, South and South-East Asia or Latin America. What is clear is that the European environment industry should be able to develop strongly on the basis of the demand
TABLE 5

Growth of the Western European

environment market, by segments

(Billions of US dollars)

\begin{tabular}{lrrr}
\hline & 1990 & 1995 & $\begin{array}{c}\text { Annual } \\
\text { growth } \\
\text { rate (\%) }\end{array}$ \\
\hline Waste management & 20.9 & 28.0 & 4.5 \\
Water and waste-water & 12.8 & 21.3 & 9.1 \\
Air pollution control & 9.6 & 12.8 & 4.3 \\
Land rehabilitation & 1.0 & 2.3 & 16.1 \\
Total & 44.3 & 64.4 & 8.5 \\
\hline
\end{tabular}

Source: United States Congress, Office of Technology Assessment (OTA), 1994.

TABLE 6

Environmental industry output, by countries, 1990

\begin{tabular}{lcc}
\hline & $\begin{array}{c}\text { Billions } \\
\text { of ECU }\end{array}$ & $\begin{array}{c}\text { As a } \\
\text { percentage }\end{array}$ \\
\hline Germany & 17.0 & 36.2 \\
France & 10.0 & 21.3 \\
United Kingdom & 7.0 & 14.9 \\
Italy & 5.0 & 10.7 \\
Netherlands & 2.7 & 5.8 \\
Spain & 1.8 & 3.8 \\
Belgium & 1.4 & 3.0 \\
Denmark & 1.0 & 2.1 \\
Portugal & 0.4 & 0.9 \\
Ireland & 0.3 & 0.6 \\
Greece & 0.3 & 0.6 \\
& & \\
Total, European & & \\
Commission & 46.9 & 100.0 \\
& & \\
European Commission & 46.9 & 23.5 \\
United States & 78.0 & 39.0 \\
Others & 75.1 & 37.6 \\
Total, World & & \\
\hline
\end{tabular}

Source: European Commission, 1994a, based on OECD data. 
TABLE 7

Number of firms and employment estimates

\begin{tabular}{lcc}
\hline & $\begin{array}{c}\text { Number of } \\
\text { firms }\end{array}$ & $\begin{array}{c}\text { Employment } \\
\text { (thousands) }\end{array}$ \\
\hline Germany & 4000 & 250 \\
France & 1500 & 90 \\
United Kingdom & 1500 & 75 \\
Italy & 2300 & 40 \\
Europe & 20000 & 600 \\
\hline
\end{tabular}

Source: European Commission,1994a, based on OECD data.

from the Eastern and Central European economies currently in transition, which have access to tied financial aid aimed at reducing pollution from domestic and industrial sources.

The urban waste water directive has been the most important single directive for the development of the environment industry in Europe, be- cause of the demand for services and technologies that it has generated: water and waste-water management absorbs $45 \%$ of Europe's environment industry output, compared with $20 \%$ for waste management, $22 \%$ for air pollution control, and $13 \%$ for others (including noise control, laboratory equipment, land rehabilitationandresource conservation). Although it is important to recognize Germany's predominance in waste water treatment and other areas, other leading member States have also established comparative advantages in particular core areas. Thus, for example, French and United Kingdom firms have also established strong positions in waste water treatment, while the Netherlands has firms with expertise in contaminated land rehabilitation. In Southern Europe, the newer entrants into the Union have considerably smaller environment industries, with little specialization (Ecotec Research and Consulting Ltd., 1994).

\section{V}

\section{The Latin American environment industry}

The environmental debates in Latin America are closely interwoven with those relating to development per se. The traditional insertion of Latin American economies into the international economy as suppliers of primary commodities has led to continual pressures on the natural environment (see Sánchez, 1993). Until the mid-twentieth century, these pressures were concentrated in rural environments, where the effects of agricultural production were leading to desertification, soil erosion, reduced soil fertility, compaction and salinization, and also in mining areas and forested environments where extraction left its marks on the locality. For urban environments, environmental pressures already existed during the nineteenth and early twentieth centuries, due to urbanization factors and the need for adequate basic services, but from the mid-twentieth century the deepening of the industrialization process intensified these pressures.

Whilst the Northern European environment industry has developed rapidly during the 1980 s and 1990s, the Latin American economies have struggled in the face of public sector financial obstacles and sluggish progress towards environmental awareness and legislation and regulation in this field. During the 1990s, national responses to environmental issues, prompted by domestic pressures but above all by international environmental concern and the imposition of trading conditions, have led to a rise in demand for environmental products and services. The bulk of the more sophisticated systems have been supplied from the North, especially from the United States.

Among the Latin American economies, Mexico has been the main target of the US environment industry. With the environmental industry market of Latin America's six largest economies valued at US\$ 2.5 billion in 1992 (40\% supplied by imports) and an expected $25 \%$ growth rate over the next few years, the promotion of non-domestic products and services is steadily increasing (Karliner, 1994) (see table 8). The considerable amounts of capital needed for the adoption of new technologies and related services come partly from bilateral and multilateral aid and development programmes. Through these programmes, the countries of the North are effectively acting as agents for their domestic producers by promoting their technologies and supplying funds to Southern governments for the purchase of this equip- 
ment. While this technology is undoubtedly valuable for reducing contamination, the political and economic foundations of this process are not based on the sustainability of Southern environments but on Northern domestic industrial criteria of competition and sales (Gligo, 1995). It is also argued that technologies that are now less suitable for complying with the current regulatory systems in the North are being exported to the South. This type of trade has strong similarities with the technology transfers of the 1960s and 1970s to Latin America, when obsolete plant and equipment (often obsolete for reasons of contamination) was transferred or sold to countries in the South to assist in their industrialization programmes. The example of Cubatão in Brazil, where a former United States oil refining plant was reconstructed in order to sustain the Brazilian "economic miracle", is a case in point. This refinery, along with numerous other plants involved in the production of chemicals and petrochemicals and in other types of heavy industrial activities, led to a concentration of the highest levels of environmental contamination in the country. The Ecotec report (Ecotec Research and Consulting, Ltd., 1994, p. 83) prepared for the United Kingdom Government on the environment industry recommends that companies should not "try to sell old technology in developing markets." This is the contemporary view, calling for the use of new plant and technology in developing markets where standards have been or are being raised and regulations tightened, but the question of how this new technology can be financed still remains. Without the "halfway house" of cheaper "second hand" technology, many firms will probably be unable to purchase the required equipment, resulting in long time-lags before the regulatory authorities are able to force firms to invest in the equipment or be penalized for failing to do so.

The transfer of obsolete equipment and outdated methods of contamination reduction will inevitably lead to a continuation of the technology gap between the North and the South, but this will also be the case if new technologies are imported. It is likely that when "end-of-pipeline" technologies give way to integrated pollution control methods within the production process, Southern firms will once again have to import new (or old) production systems developed in the North. For this reason, the environment industry is not a way of reducing the gap between North and South in terms of industrial production and economic growth, but is rather a continuation of a series of
TABLE 8

Latin Amerlcan environment markets and Imports, 1992

\begin{tabular}{lcc}
\hline & $\begin{array}{c}\text { Market } \\
\text { (millions of } \\
\text { US dollars) }\end{array}$ & $\begin{array}{c}\text { Percentage } \\
\text { imported }\end{array}$ \\
\hline Argentina & 168 & 25 \\
Brazil & 1015 & 19 \\
Mexico & 614 & 24 \\
Venezuela & 44 & 97 \\
Chile & 560 & 89 \\
Colombia & 45 & 78 \\
\hline
\end{tabular}

Source: United States Agency for International Development (USAID), in United States Congress, Office of Technology Assessment (OTA), 1994.

industrial phases, from consumer and intermediate goods production, to heavy industrial production, and finally to higher technology products, in which the time-lag in their introduction leads to the persistence of a technology gap. Osvaldo Sunkel (1980) already noted the link between development strategies and the environment almost two decades ago, and the environment industry is yet another manifestation of this connection. This in turn exacerbates the termsof-trade gap. If the national picture of the relationship between the environment and the economy is taken into consideration, as highlighted by the OECD (1996c), the role of technology, the social implications of the adoption of technology and environmental impacts (not only from the reduction in industrial emissions but also from those displaced by the new technology) must be considered within an integrated strategy. In their own way, technologies form the critical link between the environment and social systems, and environmental management policies direct this linkage (Tolba, 1980; Bustamente and Torres, 1990).

Although Birdsall and Wheeler (1993) and Wheeler and Martin (1992) rightly claim that Latin American economic openness actually encourages cleaner industry and higher anti-pollution standards, the financial, commercial and competitive implications of this openness are more complex. This is especially the case when one considers which firms are able to play a part in cleaner production due to their financial position and which are not. There are also marked differences between sectoral branches within the same national economy: for example, the restructuring of Argentina's steel industry during the 1990s 
and 1980s also led to improved environmental technologies compared with Argentina's petrochemical industry (see López and Chidiak, 1995, and Bisang and Chidiak, 1995). The threat of a two-tiered system of environmental standards and compliance is a very real one in the Latin American context. If the outcome of environmental regulations and environment industry products and services is the displacement of domestic firms by foreign firms, the economic and social implications of such environmentally-based strategies must be considered in detail (Cramer and Zegveld, 1991). Another point worthy of consideration is the gap that may exist between legal regulations and their monitoring and enforcement. In Latin America, there are many regulations on the statute books but weak public sector financial circumstances often mean that their monitoring and enforcement are under-resourced. Ramón Lopez (1992) writes that environmental policies can affect pollution intensity but that they depend critically on the implementation and enforcement of an adequate regulatory framework to internalize the true social costs of the resources used. This type of approach would ensure a more locally rooted system of laws, rather than an imported model unsympathetic to local needs and sensibilities. Latin American environmental nongovernmental organizations have persistently argued along these lines (Faure, 1995).

Mexico has been highlighted as the most outstanding Latin American market for export promotion because of its large industrial base, heightened environmental awareness due to the experience of Mexico City's poor air quality, and the 1988 General Law on Ecological Equilibrium and Environmental Protection, which provided the legislative framework for regulation and hence a market for the environment industry. Mexico's principal market has been for waste water treatment, since drinking water supply has been a government social priority, and also for air pollution control in Mexico City.

The nature of Mexico's political development has ensured that there is still a great deal of State control of basic services and utilities. For this reason, the public sector has been the principal purchaser of environmental goods and services; indeed, public sector procurement of environmental products and services is a feature of the industry all over the world. This demand has led to big market opportunities for foreign exporters, particularly for United States firms which have been backed very strongly by their government and its trade promotion agencies such as the U.S. Department of Commerce's International Trade Administration, the U.S. International Trade Commission, and the Agency for International Development. These agencies' publications advising firms of market opportunities in Mexico have been a vital factor in the development of a strong United States presence in that market. Another important factor has been the commercial relationship established by the North American Free Trade Agreement (NAFTA) and the geographical proximity of the two countries, which facilitate the movement of goods and services between them (IFC, 1992; Nadal, 1995). For Mexico, the threat of a future "dirty industry" tax on exports to the United States by industries which do not meet certain environmental standards has also been a factor taken into consideration (Low, 1992).

Whilst Mexico is now well advanced within the global environment industry as an importer, and also as a domestic supplier is certain core areas, in Latin America only Brazil can be compared with Mexico in terms of market size. Other countries such as Argentina, Venezuela and Chile, all with advanced industrial economies, require imported environmental products and services, but the need for these depends on the environmental regulations in force in each country. In the United States strategy for environment industry promotion in Latin America, Chile and Argentina are the main targets for export promotion after Mexico (U.S. Department of Commercè, 1994b). Not until their ecological awareness and demands become more clearly focused and the consequent regulations are put into place will other Latin American economies be subject to the same degree of export promotion and environment industry development as that already experienced in the case of Mexico. In these South American economies, a more open marketplace is likely to emerge within which there will be competition between United States, European and Japanese firms. In Chile, for example, with its advanced neoliberal economy, its openness to competing firms in this area will result in more open competition that goes beyond the geopolitical interests that have been prevalent in the past in such cases as those of the United States in Mexico, and Japan in South East Asia. 


\section{VI}

\section{The future: the drive for cleaner technology}

The tendency towards cleaner production processes rather than "end-of-pipeline" equipment in the United States, the European Union and Japan is very clear. The likelihood that this tendency will lead to pressures for higher environmental standards for goods imported from elsewhere is also clear, especially in international environmental fora where the displacement of "dirty" production activities from areas of higher environmental standards of production to other areas is seen as counterproductive in terms of global environmental improvement. In view of this, eco-labelling and the ability of Latin American firms to conform to trade and regulatory standards in the countries to which their exports are directed will become a paramount concern. The combination of trade restrictions with environmental restrictions may also be an important factor in closing Northern hemisphere domestic markets to particular goods.

As with the environment industries, cleaner technologies have also been quick to emerge in Europe (and also the United States and Japan); the first European Round Table on Cleaner Production Programmes was held in October 1994 at Graz, Austria, and focused on comparing and contrasting national and regional programmes, cleaner production demonstration projects, and the ideas of industrial ecology and sustainable societies (Cleaner Production, 1995). Research and development in the fields of both environment industries and cleaner technologies is intensive, and this is where the investment goes. It is for these reasons that the two fields have been joined together for purposes of definition in certain countries, but although they are similar in this respect, they are fundamentally different in essence. The high costs of research and development have been an important factor in restricting innovation to certain countries and certain firms, although the essence of cleaner production is that the firms themselves should become more highly involved in this development. Whereas the products of environment industries -such as flue gas desulphurization equipment or environmental consultancy services- can simply be purchased, cleaner production requires the rethinking of the entire process, of the social context of that process and -especially important in terms of the globalization of cleaner production strategies- the local resource base (Georg, Jorgensen and Ropke, 1990; Cramer and Zegveld, 1991; Rajagopal, 1992). Only through attention to these issues of the social context and the local resource base will it be possible to find out how to ensure the spread of cleaner technologies.

An example of clean technology development in Europe, developed under the BRITE/EURAM programme, has been coordinated by the Italian company SEPAREM. This company has linked up with project participants in Italy, Germany and France to develop a membrane which reduces the pollution generated by the textile industry. The membrane allows waste water to be purified and enables most chemical agents used in the process to be recovered; it also reduces water consumption by $80 \%$ (European Commission, 1994b). It is this ability to recover and recycle raw material inputs while at the same time reducing operating costs through low water consumption that distinguishes cleaner technology projects from end-of-pipeline technologies.

Although it is environmental consciousness and movements to that effect that have brought issues of industrial pollution onto the political and regulatory agenda, there can be no doubt that economic factors will shape the development of cleaner industries. The implementation of cleaner technologies and industrial restructuring entail very high costs which exceed the initial costs of "end-of-pipeline" equipment for example. In cost/benefit terms, it will be the future developments in particular industries and their products that will determine investment in what remains of this century. Such implementation has apparently negative short-term consequences, because it is inspired by longer-term objectives such as "first mover" advantages, the gauging of future consumption patterns based on environmental awareness, and other Porteresque benefits (Porter and Van der Linde, 1995). The OECD (1995) identifies three impediments to the wider adoption of cleaner technologies: structural (e.g., the need to amortize equipment already installed); cyclical (e.g., market trends and the financial situation of the firm); and commercial (e.g., dif- 
ficulty in marketing new processes or products). Institutional factors such as management inertia and lack of communication between engineers and executive management are also possible impediments, especially when management sees cleaner technology as an purely environmental cost rather than as a prospective benefit in terms of competitiveness.

Whilst cleaner technologies will determine the shape of the industry/environment competitiveness relationship in the short run, they must not be seen as solutions in themselves, since the notion of "zero pollution" is an abstract one. Although research reveals that $70 \%-90 \%$ of current emissions can be reduced through the use of cleaner technology, such technology will have to overcome barriers relating to various factors (Rajagopal, 1992; OECD, 1994a and b): economic (in terms of investment-return times); institutional (knowledge, information and R\&D capacity); technological (the local context for its application); educational (the human resource base for technology development); regulatory (suitability for complementing the processes concerned); information (dissemination and transfer, principally in the North/South axis); and government financial support instruments for cleaner technology promotion (as in the European Commission's Financial Instruments for the Environment (LIFE) programme which came into force in July 1992 and directs $40 \%$ of its funding to the promotion of cleaner technologies).

The magnitude of these future barriers suggests that the adoption of cleaner technologies will be geographically distinctive. For this reason, the further issue of the trade in cleaner products may well be the conditioning factor, in that the moves towards ecolabelling, environmentally friendly goods and a "greener" international consumer base may shape protectionist trade policies regarding product standards. As long ago as 1989, in Germany 2500 products were being sold with labels proclaiming them as "environmentally friendly" (European Commission, 1989), and that country now blocks products that have been manufactured using materials banned in Germany.

Within the regulatory process, there are clearly pressures for cleaner production rather than for processes that merely reduce contamination. In itself this is a major shift in direction, since environmental industries have been developed to service industrial waste and by-products. At this point it would be worth clarifying where a possible division may be made between environmental industries and cleaner production. This division is by no means clear, and this has contributed to the numerous problems associated with the measurement of environmental industries: for some countries cleaner production processes are placed together with environmental industries in their working definitions, whereas in others they are separated. For the purposes of this paper, the two are separated, because of the fundamental difference between what each tries to do.

Environment industries were established to reduce contamination, and they developed so-called "end-of-pipeline" technologies that seek to reduce emissions and the dispersal of pollutants. These contaminating products are collected and disposed of by gaseous transfer or by waste disposal in authorized sites. Consequently, these industries and technologies do not seek to transform industry. In contrast, cleaner production and processes are not focused on the wastes generated by production activities and ways of separating the good from the bad. Instead, cleaner production seeks to transform the entire production process so that the inputs, processes and outputs are all considered in terms of potential contamination. This approach calls for the reconfiguration of the industrial process in its entirety.

The strategies adopted fall into five areas: process optimization; process and product innovation; recycling and by-product recovery; resource sharing and resource optimization; and a co-productivity approach among firms (Sutter, 1989; Rajagopal, 1992). The degree to which these strategies can be applied depends very much on the maturity of the environmental market in the economy in question. Ecotec (1992) identifies three phases of market maturity: Phase I: developing markets with little environmental legislation, predominant use of end-of-pipeline technologies in environmental management, licensing arrangements or direct market penetration by foreign firms; Phase II: more developed markets with more wide-ranging environmental legislation and a greater emphasis on technological innovation in environmental management; and Phase III: mature markets where an integrated approach is taken to policy development and cleaner technologies are the focus of environmental management. Within Europe, there is a wide range of different degrees of market maturity, most clearly in a North/South division, which means that while there is a large potential market within the European Union, the establishment of Union-wide measures pertaining to environmental management 
presents bigger problems. It is evident that global environmental measures will be difficult to establish on an international cooperation basis as long as there are such clear variations, even within the North itself, among the so-called developed economies.

While the environment industries were a response to stricter regulations and environmental consciousness during the $1980 \mathrm{~s}$, it can be said that cleaner technologies are the response to the same factors in the 1990s. It is obvious that the costs of waste disposal and the basic principle of producing waste have been subjected to serious consideration and that the new focus has been on waste reduction, based on the assumption that a large part of this waste will be potentially contaminating, whether in the form of gases, water'or solid waste. The drive behind this new approach is at one and the same time environmental and economic: as politicians take up the environmental agenda in response to the pressures of interest groups, industrialists are increasingly aware of the benefits of reducing waste (as removal costs increase), the advantages of "first mover" innovation, and the pressing demands for "eco-friendly" products for labelling and marketing purposes.

\section{VII}

\section{The problem of the linear development of the environment/industry relationship}

While no-one suggests that there is a steady linear development to the environment/industry relationship -from "dirty" industries to "environmental" industries to "cleaner" industries- it is clear that Latin American industrial development will lag behind in this progression from one to another. As Joseph Karliner (1994) suggests, the importation of environmental industry products and services reveals yet another stage in industrial development and the intercontinental links of that development. Due to the high-technology nature of environmental industries and cleaner production processes, the opportunities for domestic companies to cater for national industry environmental needs are limited, so that the development of local capacity and an "endogenous development nucleus" is also restricted (Durán de la Fuente, 1991, p. 133). What is clear is that environmental demands will be supplied by foreign firms for the most part. Latin American industries will be unable to export products without the use, first of end-ofpipeline equipment, and later the adoption of cleaner production processes. The cost of such improvements will have to be internalized in one way or another. As international pressures for environmental improvement increase, such as those in the Montreal Protocols and Agenda 21, the demands on industries to improve their relationship with the local environment will undoubtedly increase likewise. These pressures may mean both a damaging impact on Latin Ameri- can manufacturing exports and an increase in industrial production costs. The positive outcomes will be improvements in environmental quality in terms of industrial emissions and contamination. The negative outcomes will relate to the labour implications of higher production costs and the long-term costs of an intensification of foreign market dominance and technology transfer that will widen the technology gap to a veritable chasm.

Joseph Karliner (1994) points to an important anomaly in the environment industry business. He notes that there are many firms which are in breach of environmental regulations (and have been subject to judicial action) but which are also suppliers of environmental goods and services. Clearly this is a serious state of affairs that must be overcome before the interaction between environmental regulations and the environment industry can lead to improvements in levels of contamination.

What this situation reveals is that the environment industry, as with any other multi-billion dollar industrial sector, is not altruistically responsive to ecological arguments or environmental quality demands. The industry functions just like any other, responding to market economics, and is likely to follow the same course as others. For this reason, the term "environment industry" must not be used in a misleading manner. As with other industries which have led to the relocation of activities, changes in the 
international division of labour (as for example in the case of the motor industry) and new patterns of trade and investment, especially in the context of the South, the environment industry should be challenged. The costs and benefits of the environment industry warrant just as much scrutiny as other industries.

Cramer and Zegveld (1991) note that the relationship between technology and environment management is often ambiguous, since there are both positive and negative effects on the environment. They stress that technology also requires changes in socio-organizational structures and consideration of the associated social contexts, as in the case of clean technologies (Rajagopal, 1992). The OECD (1996d) highlights the need for cleaner technologies to be implemented only with adequate support and changes in production patterns, which include the social component of production. What is needed is consideration of the wider implications of environment products and services, their implementation and management. As a technology-based industrial sector, the social impacts of the adoption of environment products are immense. It is these social effects that need to be considered in an integrated manner alongside the technological and economic arguments, as in the case of the regulations themselves.

What is clear in the global environment industry is that the "first movers" are located in the North and that the costs of R\&D will be passed on to the South when environmental regulations, suggested and pursued by Northern agencies (environmental groups and supranational organizations), are intensified in those countries. The costs of transition to cleaner technology will be felt most by domestic firms which will have to import equipment and services, less so by the multinational firms which will transfer technology and knowledge on an intra-firm basis or which will already have a division of their corporate structure devoted to the environment industry. It is likely that the outcome of more rigorous environmental regulation in the global context, together with the evolution of the global environment industry, which will serve this regulatory boom, will lead to a strengthening of multinational capital in Southern locations relative to domestic firms, and a greater dependence of these host countries on the trade and investment decisions of executives in the North. This shows that the environment industry in many ways typifies the nature of the globalization of economic activities, in that the perceived solutions to contem- porary ills are to be found in still further integration of the global capitalist economy.

It is also quite clear that the transfer of regulations leads to technology transfer, so that the pursuit of Northern models of environmental regulation will lead to the need for imports of new technologies. This set of circumstances will result in strong exports from the environment industry firms in the North and high costs for "dirty" industries in the South. While the economic argument is that these increased costs should be passed on to the consumer, it is more likely that, in order to remain competitive, domestic firms will be forced to rationalize, evade existing regulations where possible, or surrender to multinational competitor "buy-outs". A recurrent feature in reports on environment industry exports is that the lack of finance for meeting the demands will continue to be a serious obstacle to the global expansion of the industry, especially into the South (IFC, 1992; U.S. Congress, Office of Technology Assessment, 1994; U.S. International Trade Commission, 1995 and 1996). The degree to which development aid and multilateral financial assistance can meet these demands is limited. These demands are themselves dependent on the establishment of environmental regulations in these areas, which often follow slow trajectories through the legislature. For both these reasons, the impacts of the environment industry within the South are, and will continue to be, significant.

The least likely scenario is that a healthy domestic industrial sector will emerge, converting "dirty" industries into "clean" industries and leading to wider economic benefits within the national economy and society. The most likely scenario is that multinational firms will increase their share of the industrial sector of Southern economies, particularly the processing of natural resources such as minerals and forestry products. The outcome of this scenario is the repatriation of profits, rationalization of labour, and production for international rather than domestic markets. This scenario is an excellent one for company shareholders, but not so attractive for those who will benefit little from the buoyancy of the export-led industrial sector.

The environment industry is a rapidly evolving sector (see table 9) and there are likely to be extensive changes in the make-up of the sector and its geography, in terms of R\&D and trade orientation. A clear example of these changes is already evident in the field of trade, where the licensing of technology 
TABLE 9

Forecasts of environment industry market trends, by countries

(Billions of ECU)

\begin{tabular}{lrrc}
\hline & 1990 & 2000 & $\begin{array}{c}\text { Estimated } \\
\text { annual } \\
\text { growth (\%) }\end{array}$ \\
\hline Germany & 17.0 & 23.0 & 4.0 \\
France & 10.0 & 15.0 & 5.5 \\
United Kingdom & 7.0 & 11.0 & 6.3 \\
Italy & 5.0 & 7.7 & 6.0 \\
Netherlands & 2.7 & 3.7 & 4.1 \\
Spain & 1.8 & 3.0 & 7.4 \\
Belgium & 1.4 & 2.3 & 6.4 \\
Denmark & 1.0 & 1.2 & 2.2 \\
Portugal & 0.4 & 0.7 & 8.3 \\
Ireland & 0.3 & 0.5 & 6.5 \\
Greece & 0.3 & 0.5 & 7.4 \\
Total, EC & 46.9 & 68.6 & 4.9 \\
United States & 78.0 & 113.0 & 5.0 \\
& & & 5.5 \\
Total, World & $\mathbf{2 0 0 . 0}$ & $\mathbf{3 0 0 . 0}$ & $\mathbf{5 . 5}$ \\
\hline
\end{tabular}

Source: European Commission, 1994a, based on OECD data.

has gained growing importance compared with trade in technological equipment per se. A further example is the process of concentration within the sector, with mergers and acquisitions altering the balance of small, medium and large firms. The higher returns of the larger United States environmental firms, together with their increased $R \& D$ potential and the desire of public authorities to work with fewer companies, for monitoring and evaluation reasons, all work in favour of larger organizations.

An important question is to what extent the environment industry can maintain its current structure, incorporating such a wide range of activities, products and services. There are strong arguments for a more rigid categorization of the sector, separating various components and considering how far clean technologies can be incorporated or kept separate from the concept of environment industries. As the industry becomes more established and its current size and range of activities are more generally recognized outside the industry itself, some critical reflection on the way in which the sector came into being and how it can be consolidated or compartmentalized in the future may be in order.

The environment industry should be treated in the same way as the chemical industry, which is now subdivided into clearly defined branches. The term "environment industry" really means very little and requires greater study. The meeting on the environment industry organized by the OECD, the United States Department of Commerce and the United States Environmental Protection Agency in Washington in 1994 is a step in this direction, following on from the OECD's 1992 report which revealed the difficulties of data collection and comparison. The term "environment" has positive overtones within societies which have recognized ecological causes and provides a positive image for all the firms working within its framework, but some useful lessons could be drawn from the analogy of the drive for industrialization and its positive equation with the promotion of modernization in the 1950s and 1960s. The environment industry itself is currently addressing the failures of the latter drive. One wonders what will occur in the next century in terms of addressing the weaknesses or failures of the current environment industry, the fourth stage in Joseph Karliner's (1994) process of exporting industrial development from the North to the South, along with its accompanying ills.

Only by critical introspection can the industry act as a positive influence, giving rise to reduced contamination and improved ecological conditions and building on the recognized interface between the environment and the economy and the related issues of competitiveness (OECD, 1996c). This will require the industry to have effective regulations and controls in its own right, in order to reduce "leakages" and displacements of pollution. Also worthy of further consideration is the very rationale of the industry: the promotion of "end-of-pipeline" technologies instead of cleaner production technologies and life-cycle assessments which seek to reduce pollutants rather than deal with their emission. The future of the environment industry will be determined by its ability to involve itself in cleaner process technologies in order to move ahead in what the International Finance Corporation's Executive Vice-President, Sir William Ryrie, terms the "four Rs" of waste management: reduction, reuse, recycling and recovery. This contrasts with the current driving chain of the environment industry's "end-of-pipeline" orientation: reaction, response, treatment and disposal.

For the European environment industry, there are clearly significant gains to be made in the areas of pollution control demand where finance has been made available. With particular countries developing niche markets, it is likely that the core areas of European environment industry demand will be met inter- 
nally rather than from outside the Union, but at all events the industry is undergoing a rapid transition. With the drive towards clean technologies rather than the "end-of-pipeline" approach, it is the ability of firms to diversify their products and remain as leaders within the R\&D race which dictates developments within the industry. The European Union can act as a strong influence in this process by laying down environmental targets and encouraging firms, through a variety of integrated methods of incentives and directives, to push ahead in industrial process developments such as life cycle assessments. It is these developments which will enable European firms to compete in the global market place when the markets for "end-of-pipeline". technologies have dried up as a result of the regulatory process that will prevail in the first quarter of the next century.

Dan Noble (1996, p. 45) summarizes the situation in the United States environment industry, the largest in the world and the trend-setter to a great extent, as one in which constant innovation is essential: "Environmental equipment remains a large market, but now more than ever manufacturers must push the envelope." For Noble, "pushing the envelope" means the drive towards on-site, sourcespecific systems for recovery, recycling or treatment: what he terms Process and Prevention Technology (PPT). The idea of process and prevention is mirrored in the key features of cleaner production noted by Tim Jackson (1992): prevention (minimizing environmental hazard) and integration (with cleaner production foremost in industrial design, processes and product consumption). This drive represents a movement away from "end-of-pipeline" technologies, which are already diminishing as a percentage of total spending on environmental management strategies in the United States.

The nature of the development of the cleaner technology sector will depend on various factors, but policy instruments will be decisive in this development process. The central issue is whether cleaner technologies should be promoted from the demand or supply side: in effect, whether R\&D should lead policy and trigger market compliance, or whether the market should determine the pace of technological development. A further issue is the focus of this cleaner technology: whether it should be on the product (highlighting the life-cycle assessment approach to waste reduction), the production process at industry level, or both (OECD, 1994a and b; Berkhout,
1996). Ecotec (1992) points out that an ongoing problem for the adoption of cleaner technologies has been that the demand side has lacked the legislative impetus to exert a "pull" on environmental innovations, whilst the supply side has been too fragmented to "push" new technologies into the market place. Clearly the role of government will be critical in overcoming this obstacle (OECD, 1995), since the process of "corporate greening" has shown itself to be slow and there continues to be little concentration and coherence among environmental firms (Irwin and Hooper, 1992).

Whatever the development path of the cleaner technology sector in the developed economies, a key factor in achieving lower waste and contamination on the global scale (thus avoiding any displacement outcomes) is that of intergovernmental support, such as bilateral assistance programmes, together with lifecycle assessment and capacity-building so that firms in the developing economies can link up with the private sector in partnerships that can lead to effective environmental management strategies (Almeida, 1993; Luken and Freij, 1996). Underpinning these possibilities for reducing the cleaner technology gap between North and South is the role that should be played by international organizations such as the World Bank and UNIDO in promoting these investment and partnership opportunities, within industrial sectors and between national environment industries.

As the shift in the environment/industry relationship progresses from one of an environment industry focusing on "end-of-pipeline" technologies towards the development and application of cleaner technologies, it is already clear that cleaner technologies are not, in themselves, a panacea for industrial contamination. A more fundamental shift is required in terms of energy use and basic technologies for production, transport and consumption in order to press forward towards the goal of sustainable development (Kemp, 1994). It is this next phase of R\&D, the "next generation" (OECD, 1995), which is already underway and which will undoubtedly dictate environment/industry and industry/trade relations by 2025 . For this reason, forecasts on the development of the environment industry into the next millennium are likely to be misleading. Rather than an environment industry as it currently exists, the likelihood is that profound changes in energy use, production strategies and consumption patterns will raise different environmental issues 
demanding highly distinctive approaches and policies. In order for European industries to be aware of these rapid changes and remain competitive in the global market place, intensive public and private sector investment in R\&D will be required. The German example of growth in public environmental research and development expenditure -from $1 \%$ of all $R \& D$ in 1975 (ECU 51.2 billions) to 3. $1 \%$ in 1985 (ECU 309.3 billions): i.e., greater than all the other European countries combined (European Commission, 1989)- is an indication of the level of R\&D investment that will be required to ensure European competitiveness in the environment industry sector.

(Original: English)

\section{Bibliography}

Almeida, C. (1993): Development and Transfer of Environmentally Sound Technologies in Manufacturing: A Survey, Discussion paper, No. 58, Geneva, United Nations Conference on Trade and Development (UNCTAD).

Berkhout, F. (1996): Integrated environmental policy and industrial competitiveness, paper presented at the Workshop on Competitiveness and Environmental Policy, Cambridge, U. K., October.

Birdsall, N. and D. Wheeler (1993): Trade policy and industrial pollution in Latin America: Where are the pollution havens?, Journal of Environment and Development, vol. 2 , No. 1.

Bisang, R. and M. Chidiak (1995): Apertura económica, reestructuración productiva y medio ambiente: la siderurgia argentina en los '90, Documentos de trabajo, No. 19, Buenos Aires, Research Centre for Industrial Transformation (CENIT).

Bustamante, M. I. and S. Torres (1990): Components of an effective environmental policy, CEPAL Review, No. 41, LC/G.1631-P, Santiago, Chile, Economic Commission for Latin America and the Caribbean (ECLAC).

Cleaner Production (1995): The Newsletter of the UNEP IE Cleaner Production Network, No. 9, Geneva, Spring.

Cramer, J. and W. C. Zegveld (1991): The future role of technology in environmental management, Futures, vol. 23, No. 5, Guildford, U. K., Butterworth Scientific Limited.

Durán de la Fuente, H. (1991): Industrial and urban pollution: Policy options, CEPAL Review, No. 44, LC/G.1667-P, Santiago, Chile, ECLAC.

Ecotec Research and Consulting Ltd. (1992): The development of cleaner technologies: A strategic overview, Business Strategy and the Environment, vol. 1, No. 2, London.

(1994): The U.K. Environmental Industry: Succeeding in the Changing Global Market, London.

European Commission (1989): The emerging industries, Panorama of EC Industry, 1989, Luxembourg, Office for Official Publications of the European Community.
(1990): The environmental services industry, Panorama of EC Industry, 1990, Luxembourg, Office for Official Publications of the European Community.

(1994a): Eco-industries in the EC, Panorama of EC Industry, 1994, Luxembourg, Office for Official Publications of the European Community.

(1994b): The environment - At the Heart of European Research and Development, Brussels.

Faure, M. G. (1995): Enforcement Issues for Environmental Legislation in Developing Countries, Working paper, No. 19, Maastricht, United Nations University, INTECH (Institute for New Technologies).

Fouillard, A. (1992): Emerging Trends and lssues in Canada's Environmental Industry, Working Paper No. 8, Ontario, Canada, National Round Table on the Environment and the Economy.

Gastón, C. and M. Santiago (1996): Defining and measuring the environmental industry: Concept and approach, OECD (Organization for Economic Cooperation and Development), The Environment Industry: The Washington Meeting, Paris

Georg, S., U. Jorgensen and I. Ropke (1990): Clean technology: Innovation and environmental regulation, paper presented at the Conference on Environmental Cooperation and Policy in the Single European Market, Venice, Italy, April.

Gligo, N. (1995): The present state and future prospects of the environment in Latin America and the Caribbean, CEPAL Review, No. 55, LC/G.1858-P, Santiago, Chile, ECLAC.

Hesselberg, J. and H.M. Knutsen (1994): Location of Population-Intensive Industry in a North/South Perspective: Review of Literature F.I.L., Working Paper No. 1, Oslo, University of Oslo.

Higgins, J. (1996): Categorisation of the environmental industry: A Canadian view, OECD, The Environment Industry: The Washington Meeting, Paris.

IFC (International Finance Corporation) (1992): Investing in the Environment: Business Opportunities in Developing Countries, Washington, D. C.

Irwin, A. and P. D. Hooper (1992): Clean technology, successful innovation and the greening of industry: 
A case-study analysis, Business Strategy and the Environment, vol. 1 , No. 2.

Jackson, T. (1992): Towards Clean Production: Concepts and Principles for Guiding Technological Choice Towards Sustainable Development, Working Paper, Stockholm, Stockholm Environment Institute.

Karliner, J. (1994): The environment industry: Profiting from pollution, The Ecologist, vol. 24, No. 2.

Kemp, R. (1994): Technology and the transition to environmental sustainability: The problem of technological regime shifts, Futures, vol. 26, No. 10, Guildford, U. K., Butterworth Scientific Limited.

Leonard, H. J. (1984) Are the Environmental Regulations Driving US Industry Overseas?, Washington, D. C., The Conservation Foundation.

(1988): Pollution and the Struggle for the World Product, New York, Cambridge University Press.

López, R. (1992): The environment as a factor of production: The economic growth and trade policy linkages, in P. Low (ed.), International Trade and the Environment, World Bank Discussion Paper No. 159, Washington, D. C., World Bank.

López, A. and M. Chidiak (1995): Reestructuración productiva y gestión ambiental en la petroquímica argentina, Documentos de trabajo, No. 18, Buenos Aires, Research Centre for Industrial Transformation (CENIT).

Low, P. (1992): Trade measures and environmental quality: The implications for Mexico's exports, in P. Low (ed.), International Trade and the Environment, World Bank Discussion Paper No. 159, Washington, D. C., World Bank.

Luken, R. and A. C. Freij (1996): Cleaner industrial production in developing countries: Market opportunities for developed countries and potential cost savings for developing countries, OECD, The Environment Industry: The Washington Meeting, Paris.

Malaman, R. (1996): The Italian environment industry, $\mathrm{OECD}$, The Environment Industry: The Washington Meeting, Paris, pp. 105-139.

Munasinghe, M. and W. Cruz (1995): Economywide Policies and the Environment: Lessons from Experience, World Bank Environment Paper No. 10, Washington, D. C., World Bank.

Nadal, A. (1995): Technology, Trade and NAFTA's Environmental Regime, Working Paper No. 15, Maastricht, United Nations University, Institute for New Technologies (INTECH).

Noble, D. (1996): Redefining the environmental industry, OFCD, The Environment Industry: The Washington Meeting, Paris.

OECD (1990): Pollution Control and Abatement Expenditure in OECD Countries: A Statistical Compendium, Paris. (1992a): The OECD Environment Industry: Situation, Prospects and Government Policies, Paris.

(1992b): Technology and Environment: Trade Issues in the Transfer of Clean Technologies, Paris. (1992c): Government Policy Options to Encourage Cleaner Production and Products in the 1990's, Paris. (1993a): Pollution Abatement and Control Expenditure in OECD Countries, Paris.

(1993b): Technologies for Cleaner Production and Products: Towards Technological Revolution for Sustainable Development. Report on the OECD Programme on Technology and the Environment 1990-1993, Paris.

- (1994a): Supply Side Policies to Augment Government Support for Promoting Cleaner Technologies, Paris.

- (1994b): Reducing Environmental Pollution: Looking Back, Thinking Ahead, Paris.

(1995): Technologies for Cleaner Production and Products: Towards Technological Transformation for Sustainable Development, Paris.

(1996a): The Global Environmental Goods and Services Industry, Paris.

(1996b): The Environment Industry: The Washington Meeting, Paris

(1996c): Integrating Environment and Economy: Progress in the 1990's, Paris.

(1996d): Environmental Performance in OECD Countries: Progress in the 1990's, Paris.

Porter, M. E. and C. Van der Linde (1995): Toward a new conception of the environment-competitiveness relationship, The Journal of Economic Perspectives, vol. 9, No. 4, Nashville, TN, American Economic Association.

Rajagopal, R. (1992): Clean technology development-The ultimate solution?, Norwegian Journal of Geography, No. 46.

Sánchez Albavera, F. (1993): Natural resources: The current debate, CEPAL Review, No. 51, LC/G.1792-P, Santiago, Chile, ECLAC.

Stafford, H. A. (1985): Environmental protection and industrial location, Annals of the Association of American Geographers, vol. 75, No. 2, Washington, D. C., Association of American Geographers.

Sunkel, O. (1980): Introducción, in O. Sunkel and N. Gligo (eds.), Estilos de desarrollo y medio ambiente en la América Latina, Mexico City, Fondo de Cultura Económica, pp. 50-64.

Sutter, H.P. (1989): An integrated approach to low waste technology, International Journal of Clean Technologies, No. 1.

Tolba, M. K. (1980): Present development styles and environmental problems, CEPAL Review, No. 12, United Nations publication, Sales No. E.80.II.G.5, December. 
UNCED (United Nations Conference on Environment and Development) (1991): Global Climate Change: The Role of Technology Transfer, London, Touche Ross.

UNCTAD (1993): The Role of Technology in Environmentally-Motivated Structural Change and the Implications for International Trade, Geneva.

(1994): Report of the Workshop on the Transfer and Development of Environmentally Sound Technologies (ESTs), Geneva.

United States Congress, Office of Technology Assessment (OTA) (1994): Industry, Technology and the Environment: Competitive Challenges and Business Opportunities, Washington, D. C.

United States, Department of Commerce (1994a): Mexico: Environmental Technologies: Export Market Plan (Trade Promotion Coordinating Committee: Environmental Trade Working Group), Washington, D. C.

(1994b): Latin America Environmental Initiative (Trade Promotion Coordinating Committee: Environmental Trade Working Group), Washington, D. C.

United States, International Trade Commission (ITC) (1995): Global Competitiveness of US Environmental
Technology Industry: Municipal and Industrial Water and Wastewater, Washington, D. C.

(1996): Global Competitiveness of US Environmental Technology Industry: Air Pollution Prevention and Control, Washington, D. C.

USAID (United States Agency for International Development) (1995): Mexico's Environmental Markets, Washington, D. C., Office of Energy, Environment and Technology.

Vickery, G. and M. Iarrera (1996): Summary of the Environment Industry Expert Meeting, Washington, 13-14 October 1994, OECD, The Environment Industry: The Washington Meeting, Paris.

Walter, J. and J. Horbach (1996): The German environment industry. Present structure and development, OECD, The Environment Industry: The Washington Meeting, Paris.

Wheeler, D. and P. Martin (1992): Prices, policies and the international diffusion of clean technology: The case of wood pulp production, in P. Low (ed.), International Trade and the Environment, World Bank Discussion Paper No. 159, Washington, D. C., World Bank. 